\title{
One-pot activation-alkynylation-cyclization synthesis of 1,5-diacyl-5-hydroxypyrazolines in a consecutive three-component fashion
}

\author{
Christina Görgen 1 , Katharina Boden ${ }^{1}$, Guido J. Reiss ${ }^{2}$, Walter Frank ${ }^{2}$ \\ and Thomas J. J. Müller ${ }^{*} 1$
}

\author{
Full Research Paper \\ Address: \\ ${ }^{1}$ Heinrich-Heine Universität Düsseldorf, Institut für Organische \\ Chemie und Makromolekulare Chemie, Universitätsstraße 1, D-40225 \\ Düsseldorf, Germany and ${ }^{2}$ Heinrich-Heine Universität Düsseldorf, \\ Institut für Anorganische Chemie und Makromolekulare Chemie, \\ Universitätsstraße 1, D-40225 Düsseldorf, Germany \\ Email: \\ Thomas J. J. Müller* - ThomasJJ.Mueller@uni-duesseldorf.de \\ * Corresponding author \\ Keywords: \\ activation; alkynylation; C-C coupling; copper; cyclization; \\ multicomponent reactions
}

\author{
Beilstein J. Org. Chem. 2019, 15, 1360-1370. \\ doi:10.3762/bjoc. 15.136
}

Received: 29 March 2019

Accepted: 28 May 2019

Published: 19 June 2019

This article is part of the thematic issue "Multicomponent reactions III" and is dedicated to Prof. Dr. Dr. h.c. mult. Peter Langer on the occasion of his 50 th birthday.

Associate Editor: D. Spring

(c) 2019 Görgen et al.; licensee Beilstein-Institut. License and terms: see end of document.

\begin{abstract}
A consecutive three-component activation-alkynylation-cyclization reaction of (hetero)aryl glyoxylic acids, oxalyl chloride, arylacetylenes, and hydrazides efficiently forms 1,5-diacyl-5-hydroxypyrazolines in moderate to good yields. The structures were unambiguously corroborated by comprehensive NMR spectroscopy and X-ray structure analyses of selected derivatives.
\end{abstract}

\section{Introduction}

Pyrazoles [1,2] and pyrazolines [3-5] are privileged 1,2-diazole derivatives in a broad range of application, both in life and materials sciences. While the former are fully conjugated and can be considered as heteroaromatic $6 \pi$-systems with interesting properties as crop-protecting agents [6,7], as pharmaceutically active ingredients [8-11], as ligands [12,13], and as chromophores [14-16], the partially unsaturated $2 H$-pyrazolines have particularly attracted attention for instance as antibacterial [17], anti-inflammatory [18], antidiabetic [19], and antidepres- sive [20] agents. Especially, 1-acylpyrazolines have shown nanomolar in vitro activities against chloroquine-sensitive and resistant strains of Plasmodium falciparum and can therefore be considered for the treatment of malaria [21]. Furthermore, similar derivatives have shown micromolar and submicromolar activity against 60 selected cancer cell lines, presumably by inhibition of microtubuli formation in cancer cells [22]. More specifically, a series of 60 1,3-diaryl-1-acylpyrazolines was tested as xanthine oxygenase inhibitors that can be efficacious 

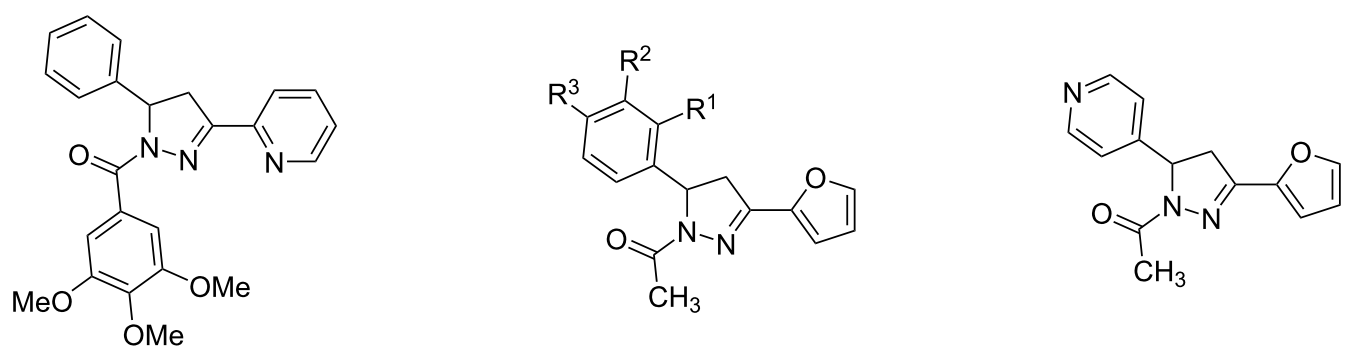

$$
\begin{aligned}
& R^{1}=N_{2}, R^{2}=R^{3}=H, R^{1}=R^{3}=H, R^{2}=N_{2} \\
& R^{1}=R^{2}=H, R^{3}=N_{2}, R^{1}=R^{2}=H, R^{3}=C l \\
& R^{1}=R^{2}=C l, R^{3}=H
\end{aligned}
$$

Figure 1: Selected anticancer active 3,5-diaryl-1-acylpyrazoline (left) and xanthine oxygenase inhibitors (center and right).

against articular gout, cancer, and inflammation, with $\mathrm{IC}_{50}$ values of four derivatives in the range of $5.3-15.2 \mu \mathrm{M}$ (Figure 1) [23].

1-Acyl-5-hydroxypyrazolines have been shown to be analgesics with a slightly improved pain-relieving efficacy than Aspirin ${ }^{\circledR}$ [24,25], and 5-nitro-2-furyl-substituted derivatives are active antibacterials against the strains $S$. aureus, A. aerogenes, E. coli and B. subtilis (Figure 2) [26,27].<smiles>[R]C1=NN(C(=O)c2ccccc2O)C([R])(O)C1[R]</smiles><smiles>[R]C1=NN(C(N)=O)C(C)(O)C1[R]</smiles><smiles>O=C(Br)C(=O)N1N=C(c2ccc([N+](=O)[O-])o2)CC1(O)C(=O)O</smiles>

$\mathrm{R}^{1}=\mathrm{H}, \mathrm{Me}$, aryl $\mathrm{R}^{1}=\mathrm{H}, \mathrm{Me}, \mathrm{Et}, \mathrm{Pr}, \mathrm{iPr}$

$\mathrm{R}^{2}=\mathrm{H}, \mathrm{Me} \quad \mathrm{R}^{2}=\mathrm{H}, \mathrm{Bu}, t-\mathrm{Bu}$, aryl

$\mathrm{R}^{3}=\mathrm{Me}, \mathrm{CF}_{3}$

Figure 2: Selected 1-acyl-5-hydroxypyrazolines with analgesic (left, center) and antibacterial activity (center and right).

In addition, 1-acyl-5-hydroxypyrazolines are bidentate ligands for zinc complexes and by virtue of being ring tautomers of $\beta$-enolhydrazones they can also act as tridentate ligands for nickel $[28]$ and tin $[29,30]$ complexes. In contrast, dimethylzinc forms dimeric complexes where the 1-acyl-5-hydroxypyrazoline acts as a bidentate ligand [31]. Upon treatment with TMEDA mononuclear complexes with concomitant ring opening to give a seven-membered bidentate chelate are generated.

Although numerous syntheses of pyrazolines [3-5] in general and 1-acyl-5-hydroxypyrazolines [24-26] specifically have been published employing a cyclizing addition of an acylhydrazone to the carbonyl group as a ring-forming reaction [32-40], their diversity-oriented one-pot synthesis in a multicomponent approach has remained unexplored to date. In the course of our program directed to develop multicomponent syntheses of heterocycles by transition-metal catalysis $[41,42]$ we conceptualized catalytic entries to alkynones and alkynediones as suitable intermediates in addition-cyclocondensation syntheses of numerous heterocycles, which can indeed be prepared by consecutive multicomponent reactions [43-47]. Particularly interesting are alkynediones, because, as densely functionalized trielectrophiles, the alkyne, ynone and dicarbonyl functionalities can be selectively addressed. We have established two complementary one-pot pathways to alkynediones, a glyoxylation-alkynylation (GA) [48] and an activation-alkynylation (AA) [49] sequence, which both take advantage of a copper-catalyzed alkynylation of the intermediary formed (hetero)arylglyoxyl chloride (Scheme 1). The alkynediones can be subsequently transformed, still in the same reaction vessel, to quinoxalines [48,50-52], pyrimidines [48,49], and 5-acylpyrazoles $[48,49]$. The latter 5-acylpyrazole arose after work-up from the three-component AA-cyclocondensation synthesis employing Boc-hydrazine as a binucleophilic hydrazide substrate. Based on our attempts to isolate potential 1,5-diacylpyrazole precursors we discovered that 1,5-diacyl-5-hydroxypyrazolines are the intermediary products. Here, we report on the novel three-component AA-condensation-cyclization synthesis of 1,5-diacyl-5hydroxypyrazolines.

\section{Results and Discussion}

In our initial study [49], the three-component AA-cyclocondensation synthesis, starting from phenylglyoxylic acid (1a), phenylacetylene (2a), and Boc-hydrazide (4a) through the formation of 1,4-diphenylbut-3-yne-1,2-dione (3a), with subsequent $N$-deacylation as the consequence of basic work-up (Scheme 2), furnished 5-benzoyl-3-phenyl-1H-pyrazole (6a) in $41 \%$ isolated yield. 


$$
\begin{aligned}
& \text { glyoxylation-alkynylation (GA) sequence } \\
& \begin{array}{ll}
\mathrm{R}^{1} \mathrm{H} & (\mathrm{COCl})_{2}(1.0 \text { equiv }) \\
^{1}=\pi \text {-nucleophile }
\end{array} & \begin{array}{c}
\text { ether solvents } \\
0-100^{\circ} \mathrm{C}, 2-24 \mathrm{~h}
\end{array}
\end{aligned} }
\end{array}
$$

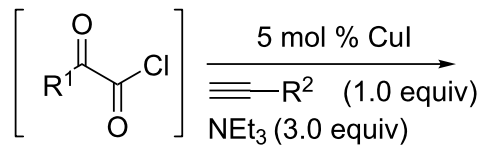

$$
\begin{aligned}
& \left.\begin{array}{ll}
\quad & (\mathrm{COCl})_{2}(1.0 \text { equiv) }
\end{array}\right\} \begin{array}{l}
\mathrm{rt}, 24 \mathrm{~h} \\
\mathrm{R}^{2}=\text { (hetero)aryl, } \mathrm{Si}(\mathrm{iPr})_{3}
\end{array} \\
& \text { 1,4-dioxane } \\
& 50^{\circ} \mathrm{C}, 4 \mathrm{~h} \\
& \mathrm{R}^{1}=\text { (hetero)aryl }
\end{aligned}
$$

21 examples by GA sequence (33-77\%, if isolated)<smiles>[R]C#CC([R])=O</smiles>

7 examples by AA sequence (34-65\%, if isolated)

Scheme 1: Glyoxylation-alkynylation (GA) and activation-alkynylation (AA) synthesis of alkynediones in a one-pot fashion.

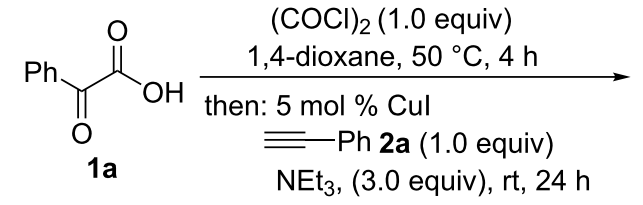

then: BocNH-NH

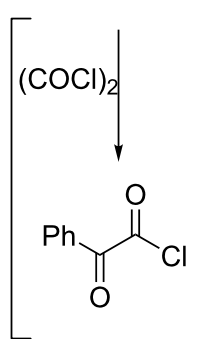
$\mathrm{MeOCH} \mathrm{CH}_{2} \mathrm{OH}, 100^{\circ} \mathrm{C}, 24 \mathrm{~h}$

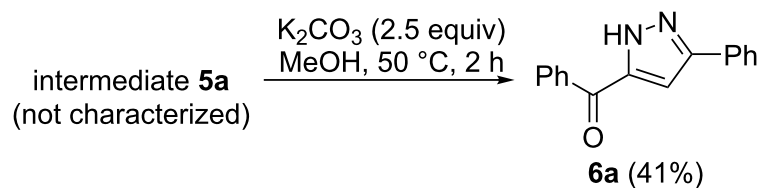

6 a $(41 \%)$

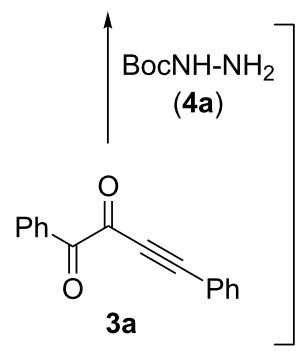

Scheme 2: Consecutive three-component synthesis to give 5-benzoyl-3-phenyl-1H-pyrazole (6a) after alkaline deacylation of intermediate 5 a.

In addition to spectroscopic assignment the structure of $\mathbf{6 a}$ has now been corroborated by an X-ray structure analysis showing infinite chains of molecules $6 \mathbf{a}$ formed by intermolecular hydrogen bonding between the pyrazole N1 and the carbonyl O1 (Figure 3) [53].

The first assumption was that the tentative intermediate 5a could be a 1,5-diacylpyrazole. However, upon performing the terminal cyclization step starting from 1,4-diphenylbut-3-yne1,2-dione (3a) and Boc-hydrazine (4a) under identical conditions 1-Boc-5-benzoyl-5-hydroxypyrazoline was isolated in $83 \%$ yield (Scheme 3 ).

The molecular structure was additionally corroborated by $\mathrm{X}$-ray structure analysis showing that the assignment of intermediate 5a was not a fully unsaturated pyrazole (Figure 4) [53].

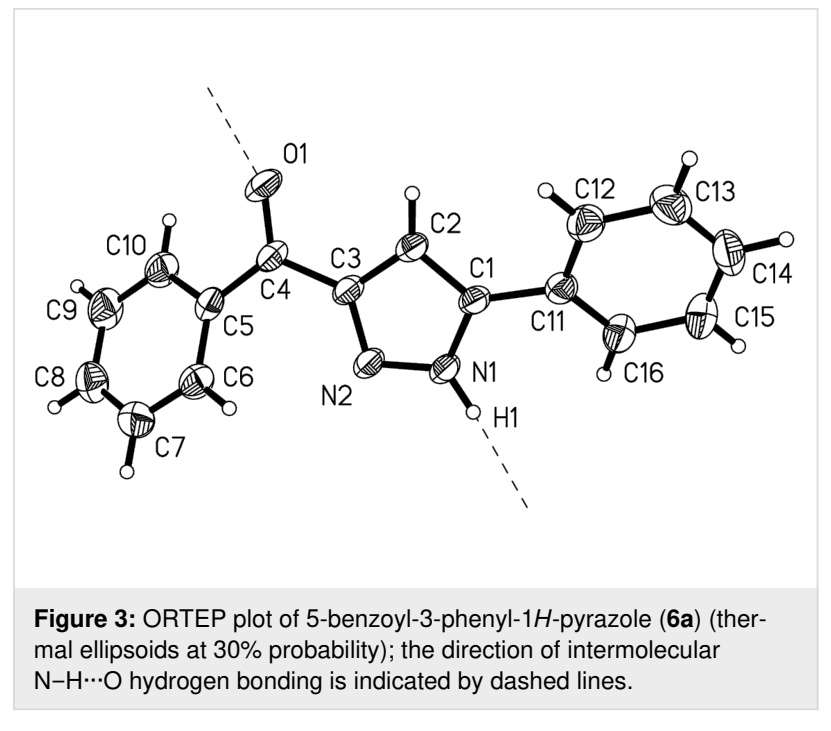




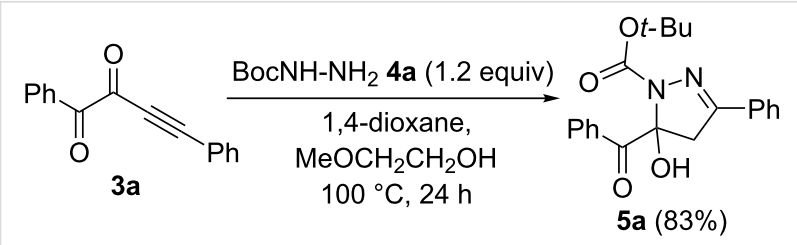

Scheme 3: Cyclization of 1,4-diphenylbut-3-yne-1,2-dione (3a) and Boc-hydrazine $(\mathbf{4 a})$ to give intermediate $5 \mathbf{a}$.

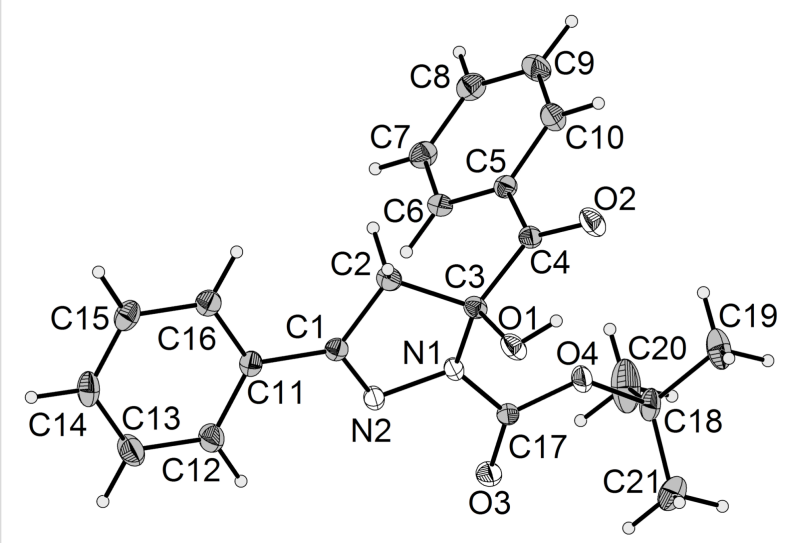

Figure 4: Ellipsoid plot of 1-Boc-5-benzoyl-5-hydroxypyrazoline 5a

Therefore, we set out to optimize the one-pot synthesis of 1,5diacyl-5-hydroxypyrazolines by choosing the model reaction of phenylglyoxylic acid (1a), phenylacetylene (2a), and benzoyl hydrazide (4b) giving 1,5-diacyl-5-hydroxypyrazoline $\mathbf{5 b}$, where the reaction times $t_{1}$ and $t_{2}$, as well as the conditions of the cyclization step needed to be optimized (Scheme 4).

A quick optimization screening of the activation-alkynylation synthesis of 1,4-diphenylbut-3-yne-1,2-dione (3a) revealed that the use of $\mathrm{KOH}$ dried triethylamine instead of the initial precon- ditioning ( $\mathrm{Na}$ /benzophenone dried) led to a reduction of the reaction time $t_{1}$ from 24 to $15 \mathrm{~h}$ (see Supporting Information File 1, Table S1). In addition, the concentration could be doubled and the obtained yield of diphenylbut-3-yne-1,2-dione (3a) increased from 63 to $76 \%$.

The terminal cyclization step, consisting of a Michael addition of benzoyl hydrazide (4b) to diphenylbut-3-yne-1,2-dione (3a) followed by a cyclizing addition of the central hydrazide nitrogen atom to the carbonyl group, was monitored by GC-MS and optimized with respect to temperature $T$, reaction time $t_{2}$, and the alcohol additive (Table 1).

A ratio of 1.2 equiv of hydrazide $4 \mathbf{b}$ to 1.0 equiv of $\mathbf{3 a}$ turned to be optimal for achieving full conversion (Table 1, entries 7-16) and at a reaction temperature of $175^{\circ} \mathrm{C}$ the reaction time of 5 min was identified to achieve full conversion with very good to excellent yields of isolated 1,5-diacyl-5-hydroxypyrazoline 5b (Table 1, entries 12-16). Although ethylene glycol as a cosolvent (Table 1, entry 13) gave slightly higher yields and ethanol furnished slightly lower yields (Table 1, entry 14), 2-methoxyethanol not only gave high yields of $\mathbf{5 b}$, but also proved to be practical with respect to work-up. Upon comparison between dielectric and conductive heating the reaction in the microwave cavity gave no detectable difference in reaction time and yield. All these optimized conditions were therefore directly employed in the consecutive one-pot sequence. However, some adjustments in the final step were necessary because an increase of pressure was detected under dielectric heating. Therefore, the consecutive process was optimized with respect to the terminal step (Table 2).

In the sequence dielectric heating gave considerably lower yields (Table 2, entries 1-3) than in the separated process<smiles>O=C(O)C(=O)c1ccccc1</smiles>

1a<smiles>CC(C)(C)OC(=O)C(=O)c1ccccc1</smiles>

$(\mathrm{COCl})_{2}(1.0$ equiv)

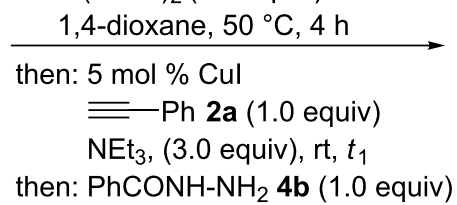
$\mathrm{ROH}, T, t_{2}$ 
Table 1: Optimization of the cyclization step of 1,5-diacyl-5-hydroxypyrazoline $5 \mathbf{b}^{\text {a }}$

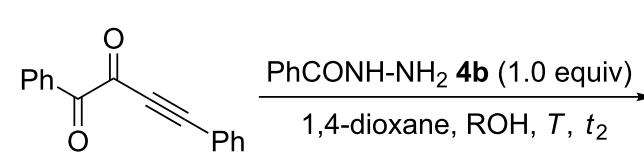

3a<smiles>O=C(c1ccccc1)N1N=C(c2ccccc2)CC1(O)C(=O)c1ccccc1</smiles>

$5 b$

\begin{tabular}{|c|c|c|c|c|}
\hline entry & $\mathrm{ROH}[\mathrm{mL}]$ & $T\left[{ }^{\circ} \mathrm{C}\right]$ & $t_{2}[\mathrm{~min}]$ & 1,5-diacyl-5-hydroxypyrazoline $5 \mathbf{b}(\%)^{b}$ \\
\hline $1^{c, d}$ & 2-methoxyethanol (0.2) & 100 & 60 & incomplete conversion ${ }^{e}$ (n.i.) \\
\hline $2^{c, d}$ & 2-methoxyethanol $(0.2)$ & 150 & 60 & incomplete conversione (n.i.) \\
\hline $3^{d, f}$ & 2-methoxyethanol $(0.2)$ & 150 & 60 & complete conversion $^{\mathrm{e}}$ (n.i.) \\
\hline $4^{\mathrm{d}, \mathrm{g}}$ & 2-methoxyethanol $(0.2)$ & 150 & 60 & complete conversion $^{\mathrm{e}}$ (n.i.) \\
\hline $5^{\mathrm{d}, \mathrm{h}}$ & 2-methoxyethanol $(0.2)$ & 150 & 60 & complete conversion $^{\mathrm{e}}$ (n.i.) \\
\hline $6^{\mathrm{d}, \mathrm{i}}$ & 2-methoxyethanol $(0.2)$ & 150 & 60 & incomplete conversione (n.i.) \\
\hline $7^{\mathrm{d}, \mathrm{h}}$ & 2-methoxyethanol (0.2) & 150 & 30 & complete conversion $^{\mathrm{e}}$ (n.i.) \\
\hline $8^{\mathrm{d}, \mathrm{h}}$ & 2-methoxyethanol (0.2) & 150 & 15 & complete conversion $^{\mathrm{e}}$ (n.i.) \\
\hline $9^{d, h}$ & 2-methoxyethanol $(0.2)$ & 150 & 5 & incomplete conversion ${ }^{\mathrm{e}}$ (n.i.) \\
\hline $10^{\mathrm{d}, \mathrm{h}}$ & 2-methoxyethanol (0.2) & 100 & 10 & incomplete conversion ${ }^{\mathrm{e}}$ (n.i.) \\
\hline $11^{\mathrm{d}, \mathrm{h}}$ & 2-methoxyethanol (0.2) & 125 & 10 & incomplete conversione (n.i.) \\
\hline $12^{\mathrm{d}, \mathrm{h}, \mathrm{j}}$ & 2-methoxyethanol $(0.2)$ & 175 & 5 & full conversion ${ }^{\mathrm{e}}(94)$ \\
\hline $13^{\mathrm{d}, \mathrm{h}, \mathrm{j}}$ & ethylene glycol (0.2) & 175 & 5 & full conversione (96) \\
\hline $14^{\mathrm{d}, \mathrm{h}, \mathrm{j}}$ & ethanol $(0.2)$ & 175 & 5 & full conversione $(87)$ \\
\hline $15^{\mathrm{k}}$ & 2-methoxyethanol (0.2) & 175 & 5 & full conversion ${ }^{\mathrm{e}}(90)$ \\
\hline $16^{h, l, j}$ & 2-methoxyethanol $(0.2)$ & 175 & 5 & full conversione (93) \\
\hline
\end{tabular}

${ }^{\mathrm{a}} C_{0}(3 \mathbf{a})=0.17 \mathrm{M} ; 1,4$-dioxane $(1.0 \mathrm{~mL})$. ${ }^{\mathrm{b}}$ Isolated yield $\left(\mathrm{n} . \mathrm{i} .=\right.$ not isolated). ${ }^{\mathrm{c}} C_{0}(\mathbf{4 b})=0.17 \mathrm{M}$. ${ }^{\mathrm{d}}$ Dielectric heating in a microwave cavity $(T$ is the set temperature and $t_{2}$ is the hold time). ${ }^{e}$ As monitored by GC-MS. ${ }^{\mathrm{f}} C_{0}(\mathbf{4 b})=0.25 \mathrm{M} .{ }^{9} C_{0}(\mathbf{4 b})=0.21 \mathrm{M} .{ }^{\mathrm{h}} C_{0}(\mathbf{4 b})=0.20 \mathrm{M} .{ }^{\mathrm{i}} C_{0}(\mathbf{4 b})=0.18 \mathrm{M}$. ${ }^{\mathrm{j} O \mathrm{O}} \mathrm{a}$ $1.00 \mathrm{mmol}$ scale (3a). ${ }^{\mathrm{K}} \mathrm{On}$ a $1.00 \mathrm{mmol}$ scale $(\mathbf{3 a}), c_{0}(\mathbf{3 a})=0.34 \mathrm{M} ; c_{0}(\mathbf{4 b})=0.40 \mathrm{M}$. 1,4-Dioxane $(1.0 \mathrm{~mL})$. 'Conductive heating in an oil bath at preheated temperature $T$.

Table 2: Optimization of the consecutive three-component synthesis of 1,5-diacyl-5-hydroxypyrazoline $\mathbf{5 b}$.

$$
\begin{aligned}
& (\mathrm{COCl})_{2} \text { (1.0 equiv) } \\
& \text { 1,4-dioxane, } 50{ }^{\circ} \mathrm{C}, 4 \mathrm{~h} \\
& 1 a
\end{aligned}
$$

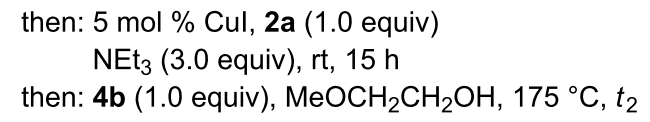

\begin{tabular}{llll}
\hline entry & $c_{0}(\mathbf{1 a})$ & $t_{2}[\mathrm{~min}]$ & 1,5-diacyl-5-hydroxypyrazoline $\mathbf{5 b}$, yield [\%] $^{\mathrm{a}}$ \\
\hline $1^{\mathrm{b}}$ & $0.4 \mathrm{M}$ & 5 & 37 \\
$2^{\mathrm{b}}$ & $0.25 \mathrm{M}$ & 5 & 32 \\
$3^{\mathrm{b}}$ & $0.25 \mathrm{M}$ & 10 & 35 \\
$4^{\mathrm{c}}$ & $0.4 \mathrm{M}$ & 10 & no product formation \\
$5^{\mathrm{e}, \mathrm{f}}$ & $0.4 \mathrm{M}$ & 5 & no product formation \\
$6^{\mathrm{e}}$ & $0.4 \mathrm{M}$ & 10 & 64 \\
$7^{\mathrm{e}}$ & $0.4 \mathrm{M}$ & 20 & 69 \\
$\mathbf{8}^{\mathrm{e}}$ & $\mathbf{0 . 4 ~ M}$ & $\mathbf{3 0}$ & $\mathbf{7 8}$ \\
$9^{\mathrm{e}}$ & $0.4 \mathrm{M}$ & 45 & 79 \\
\hline
\end{tabular}

alsolated yield. bDielectric heating in a microwave cavity ( $T$ is set to $175^{\circ} \mathrm{C}$ and $t_{2}$ is the hold time). ${ }^{c}$ Dielectric heating in a microwave cavity ( $T$ is set to $150{ }^{\circ} \mathrm{C}$ and $t_{2}$ is the hold time). ${ }^{\mathrm{d}}$ As monitored by GC-MS. ${ }^{\mathrm{e}}$ Conductive heating in an oil bath at preheated temperature $T=175{ }^{\circ} \mathrm{C}$. ${ }^{\mathrm{f}} 2.00$ equiv of $\mathrm{NEt}_{3}$ were added. 
(Table 1, entries 12-15). However, conductive heating, which already gave comparable results in the terminal cyclization step (Table 1, entry 16), is obviously better suited to achieve full conversion and, ultimately, slightly longer heating also gives rise to good yields (Table 2, entries 6-9).

Taking into account the combined yield of $71 \%$ for both individually performed steps (ynedione formation with $76 \%$ and cyclization with 94\%) is slightly lower than that of the one-pot sequence with $78 \%$ (Table 2 , entry 8 ), the consecutive threecomponent process clearly is superior. With four bond-forming steps (activation, alkynylation, Michael addition, and cyclization) the average yield per bond-forming step accounts to $94 \%$.
With the optimized conditions of the consecutive three-component synthesis in hand (hetero)arylglyoxylic acids $\mathbf{1}$, oxalyl chloride, arylacetylenes $\mathbf{2}$, and hydrazides $\mathbf{4}$ were reacted in 1,4dioxane and in the presence of catalytic amounts of copper(I) iodide in a one-pot activation-alkynylation-cyclization sequence to give 1,5-diacyl-5-hydroxypyrazoline 5 after flash chromatography on silica gel in moderate to good yields (Scheme 5, Table 3).

The structures of the 1,5-diacyl-5-hydroxypyrazolines 5 were unambiguously assigned by ${ }^{1} \mathrm{H}$ and ${ }^{13} \mathrm{C}$ NMR spectroscopy, in selected cases by NOESY, HSQC, and HMBC experiments, as well as by EI mass spectrometry and the elemental composition<smiles>[R]C(=O)C(=O)O</smiles>

1

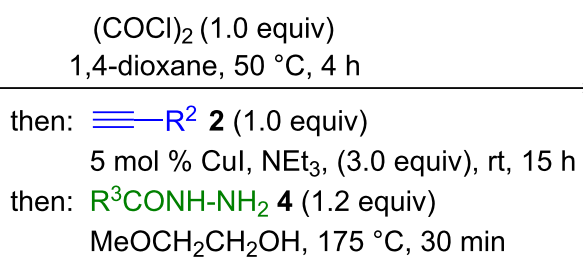

$(\mathrm{COCl})_{2}$ (1.0 equiv)

1,4-dioxane, $50{ }^{\circ} \mathrm{C}, 4 \mathrm{~h}$

then: $\equiv \mathrm{R}^{2} 2$ (1.0 equiv)

$5 \mathrm{~mol} \%$ Cul, NEt 3 , (3.0 equiv), rt, $15 \mathrm{~h}$

then: $\mathrm{R}^{3} \mathrm{CONH}-\mathrm{NH}_{2} \mathbf{4}$ (1.2 equiv)

$\mathrm{MeOCH}_{2} \mathrm{CH}_{2} \mathrm{OH}, 175^{\circ} \mathrm{C}, 30 \mathrm{~min}$<smiles>[R]C(=O)N1N=C([R])CC1(O)C([R])=O</smiles>

5 (17 examples, $29-78 \%)$

Scheme 5: One-pot activation-alkynylation-cyclization synthesis of 1,5-diacyl-5-hydroxypyrazolines 5.

Table 3: Consecutive three-component synthesis of 1,5-diacyl-5-hydroxypyrazolines 5.

\begin{tabular}{|c|c|c|c|c|}
\hline entry & $\begin{array}{l}\text { glyoxylic acid } \\
\mathrm{R}^{1} \mathrm{COCO}_{2} \mathrm{H}_{1}\end{array}$ & $\begin{array}{c}\text { alkyne } \\
\mathrm{R}^{2} \mathrm{C} \equiv \mathrm{CH} 2\end{array}$ & $\begin{array}{c}\text { hydrazide } \\
\mathrm{R}^{3} \mathrm{CONHNH}_{2} 4\end{array}$ & $\begin{array}{c}\text { 1,5-diacyl-5-hydroxypyrazoline } 5 \\
\text { yield }\end{array}$ \\
\hline
\end{tabular}

$2^{a}$

1a

$\mathrm{R}^{1}=\mathrm{Ph}(\mathbf{1} \mathbf{a})$

$R^{2}=P h(2 a)$

2a

$\mathrm{R}^{3}=p-\mathrm{MeC}_{6} \mathrm{H}_{4}(\mathbf{4 c})$ 1a
$2 a$<smiles>O=C(c1ccccc1)N1N=C(c2ccccc2)CC1(O)C(=O)c1ccccc1</smiles><smiles>Cc1ccc(C(=O)N2N=C(c3ccccc3)CC2(O)C(=O)c2ccccc2)cc1</smiles>

$5 c(55 \%)$<smiles>O=C(c1ccc(Br)cc1)N1N=C(c2ccccc2)CC1(O)C(=O)c1ccccc1</smiles>

5d (41\%) 
Beilstein J. Org. Chem. 2019, 15, 1360-1370.

Table 3: Consecutive three-component synthesis of 1,5-diacyl-5-hydroxypyrazolines 5 . (continued)

4

$1 \mathbf{a}$

5

$1 \mathbf{a}$

$2 a$

$R^{3}=2$-furyl (4f)

6

$1 a$

$2 a$

$$
\mathrm{R}^{3}=\mathrm{PhCH}_{2}(\mathbf{4 g})
$$

7

$1 a$

$2 a$

$\mathrm{R}^{3}=\mathrm{iPr}(\mathbf{4 h})$

8

$1 a$

$2 a$

$\mathrm{R}^{3}=$ cyclopropyl (4i)

9

$1 a$

$2 a$

$\mathrm{R}^{3}=t-\mathrm{Bu}(\mathbf{4} \mathbf{j})$

10

$1 a$

$2 a$

$\mathrm{R}^{3}=n-\operatorname{Pr}(\mathbf{4 k})$

11

$1 a$

$\mathrm{R}^{2}=p-\mathrm{MeOC}_{6} \mathrm{H}_{4}(\mathbf{2 b})$

4b<smiles>O=C(c1cccs1)N1N=C(c2ccccc2)CC1(O)C(=O)c1ccccc1</smiles><smiles>O=C(c1ccccc1)N1N=C(c2ccccc2)CC1(O)C(=O)c1ccccc1</smiles>

$5 f(67 \%)$<smiles>O=C(Cc1ccccc1)N1N=C(c2ccccc2)CC1(O)C(=O)c1ccccc1</smiles>

5 g (59\%)

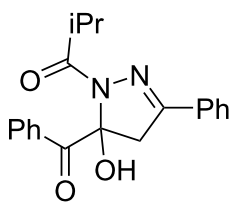

5 h $(66 \%)$

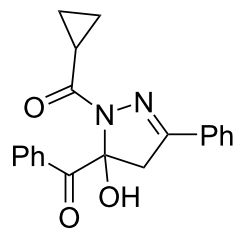

$5 i(69 \%)$<smiles>CC(C)(C)C(=O)N1N=C(c2ccccc2)CC1(O)C(=O)c1ccccc1</smiles>

5j (58\%)<smiles>CCCC(=O)N1N=C(c2ccccc2)CC1(O)C(=O)c1ccccc1</smiles>

5k $(33 \%)$

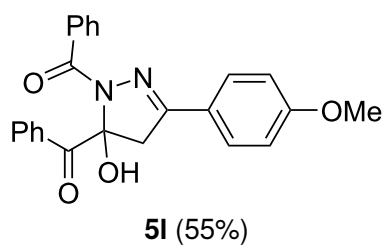

1366 
Table 3: Consecutive three-component synthesis of 1,5-diacyl-5-hydroxypyrazolines 5 . (continued)

12

$1 \mathbf{a}$

$\mathrm{R}^{2}=p-t-\mathrm{BuC}_{6} \mathrm{H}_{4}(\mathbf{2 c})$

13

$1 a$

$\mathrm{R}^{2}=p-\mathrm{FC}_{6} \mathrm{H}_{4}(\mathbf{2 d})$

$\mathrm{R}^{2}=p-\mathrm{NCC}_{6} \mathrm{H}_{4}(\mathbf{2 e})$

$2 a$

$2 a$

$2 b$
$4 b$<smiles>CC(C)(C)O[13C](=O)c1ccc(C2=NN(C(=O)c3ccccc3)C(O)(C(=O)c3ccccc3)C2)cc1</smiles>

$4 b$<smiles>O=C(c1ccccc1)N1N=C(c2ccc(F)cc2)CC1(O)C(=O)c1ccccc1</smiles>

5n $(66 \%)$<smiles>N#Cc1ccc(C2=NN(C(=O)c3ccccc3)C(O)(C(=O)c3ccccc3)C2)cc1</smiles>

$50(29 \%)$<smiles>Cc1cc(C)c(C(=O)C2(O)CC(c3ccccc3)=NN2C(=O)c2ccccc2)c(C)c1</smiles>

$5 p(47 \%)$<smiles>O=C(c1ccccc1)N1N=C(c2ccccc2)CC1(O)C(=O)c1ccccc1</smiles>

$5 q(73 \%)$

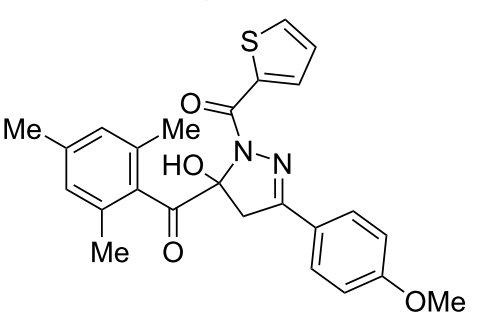

$5 r(38 \%)$

aReaction time $t_{2}=20 \mathrm{~min}$.

was confirmed by combustion analyses. Additionally, the structure was corroborated by an X-ray structure analysis of compound $5 \mathbf{r}$ showing dimers held together by inter- and intramolecular hydrogen bonding (Figure 5) [53].

The three-component synthesis allows addressing three points of diversity and especially for the hydrazide substrate $\mathbf{4}$ all different types of (hetero)aromatic, aliphatic, and alicyclic substituents $\mathrm{R}^{3}$ are well tolerated in the sequence (Table 3, entries 1-10). The alkynes 2 can bear electron-donating and electron- withdrawing substituents $\mathrm{R}^{2}$ (Table 3, entries 1, 11-14), however, for the electron-poor cyano substituent a somewhat lower yield of the title compound is obtained (Table 3, entry 14). Finally, the substituents $\mathrm{R}^{1}$ of the glyoxylic acids $\mathbf{1}$ can be aromatic, heteroaromatic and even sterically demanding (Table 3, entries 1, 15-17).

All attempts to dehydrate 1,5-diacyl-5-hydroxypyrazoline $\mathbf{5 b}$ under alkaline or Brønsted acidic conditions were accompanied by simultaneous deacylation of substituent $\mathrm{R}^{3}$ finally furnishing 

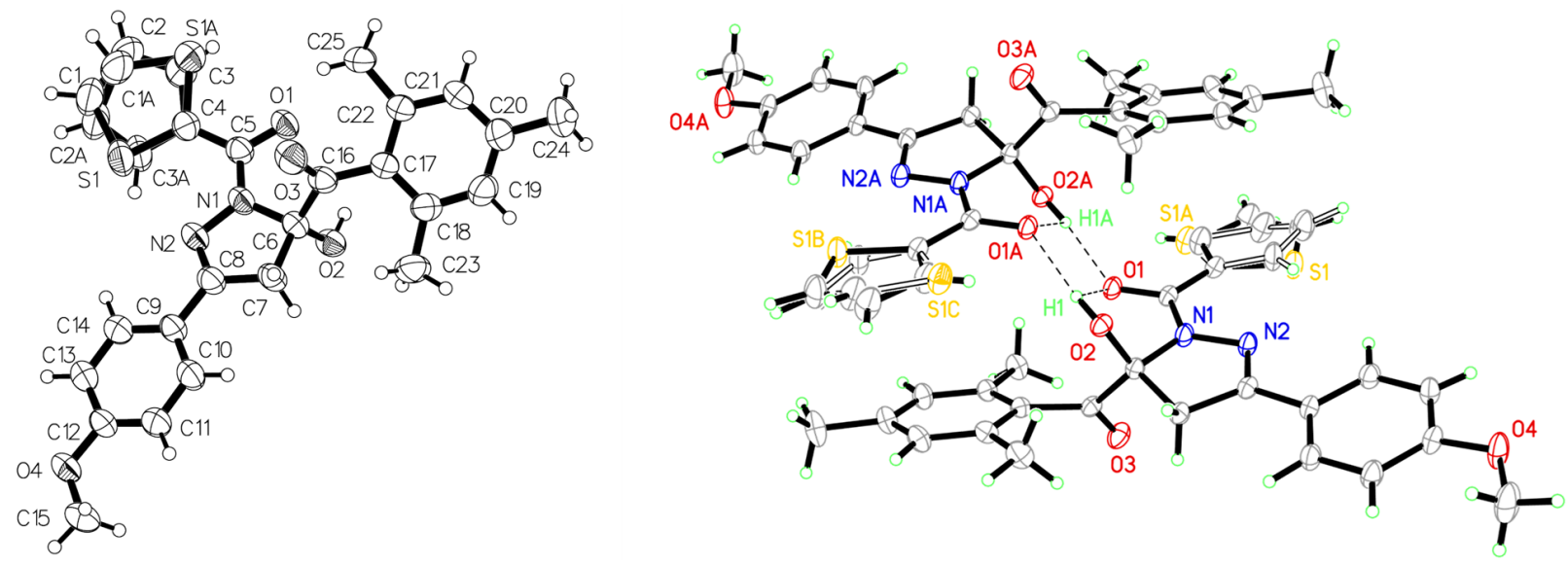

Figure 5: ORTEP plot and dimer of compound $\mathbf{5 r}$ (thermal ellipsoids at $30 \%$ probability).

5-(hetero)aroyl-3-(hetero)aryl-1H-pyrazole 6a (for attempted dehydrative aromatization, see Supporting Information File 1 , Table S5), as already reported for alkaline deprotection-aromatization [49]. However, compound $\mathbf{5 b}$ is stable against water and weakly basic conditions. This indicates that 1,5-diacyl-5hydroxypyrazolines might act as acyl transferring agents under certain conditions.

\section{Conclusion}

In summary we could elucidate that the consecutive three-component activation-alkynylation-cyclization sequence of (hetero)arylglyoxylic acids, oxalyl chloride, arylacetylenes, and hydrazides does not form aromatic pyrazoles, but rather 1,5diacyl-5-hydroxypyrazolines, i.e., the aromatizing elimination of water does not occur under these neutral conditions. This novel one-pot synthesis of 1,5-diacyl-5-hydroxypyrazolines is concise, highly efficient and diversity-oriented. The deacylating aromatization of the title compounds under weakly alkaline or acidic conditions indicates acyl-transfer ability. Furthermore, the peculiar reactivity of the ynedione intermediate calls for more sophisticated cyclizing processes, eventually in a onepot fashion. Further studies exploring the dense electrophilic reactivity of ynediones in consecutive multicomponent reactions are still underway.

\section{Experimental}

Typical procedure for the three-component synthesis of compound 5b: In an oven-dried Schlenk flask equipped with a magnetic stirring bar and screw cap were placed glyoxylic acid 1a $(150 \mathrm{mg}, 1.00 \mathrm{mmol})$ and dry 1,4 -dioxane $(2.5 \mathrm{~mL})$ under argon. Then, oxalyl chloride $(0.09 \mathrm{~mL}, 1.00 \mathrm{mmol})$ was added dropwise at room temperature (external water bath) and the reaction mixture was stirred at $50{ }^{\circ} \mathrm{C}$ (preheated oil bath) for
$4 \mathrm{~h}$. After the mixture had cooled to room temperature, $\mathrm{CuI}$ (10 $\mathrm{mg}, 0.05 \mathrm{mmol})$, phenylacetylene $(\mathbf{2 a}, 0.11 \mathrm{~mL}$, $1.00 \mathrm{mmol})$, and dry triethylamine $(0.42 \mathrm{~mL}, 3.00 \mathrm{mmol})$ were successively added. Stirring at room temperature (external water bath) was continued for $15 \mathrm{~h}$. Then, phenylhydrazide (3b, $163 \mathrm{mg}, 1.20 \mathrm{mmol})$ and 2-methoxyethanol $(1.0 \mathrm{~mL})$ were added and the reaction mixture was stirred at $175^{\circ} \mathrm{C}$ (preheated oil bath) for $30 \mathrm{~min}$. After cooling to room temperature deionized water $(5 \mathrm{~mL})$ was added and the mixture was extracted with dichloromethane $(4 \times 5 \mathrm{~mL})$. The combined organic phases were dried with anhydrous sodium sulfate and the solvents were removed in vacuo. The crude product was adsorbed on celite ${ }^{\odot}$ and purified by flash chromatography on silica gel (petroleum ether $40-60{ }^{\circ} \mathrm{C} /$ ethyl acetate $5: 1$ ) to give analytically pure 1,5-dibenzoyl-5-hydroxy-3-phenylpyrazoline (5b, $291 \mathrm{mg}, 78 \%$ ) as colorless solid. $R_{f}=0.15$ (petroleum ether/ ethyl acetate 5:1, detected with a hand-held UV lamp at 254 and $365 \mathrm{~nm})$. Mp $152{ }^{\circ} \mathrm{C} ;{ }^{1} \mathrm{H}$ NMR $\left(\mathrm{CDCl}_{3}, 300 \mathrm{MHz}\right) \delta 3.54(\mathrm{~d}$, $J=18.5 \mathrm{~Hz}, 1 \mathrm{H}), 3.76(\mathrm{~d}, J=18.5 \mathrm{~Hz}, 1 \mathrm{H}), 5.60-6.08(\mathrm{br}, 1 \mathrm{H})$, 7.36-7.62 (m, 9H), 7.72-7.83 (m, 2H), 7.90-8.05 (m, 4H); ${ }^{13} \mathrm{C} \mathrm{NMR}\left(\mathrm{CDCl}_{3}, 75 \mathrm{MHz}\right) \delta 45.6\left(\mathrm{CH}_{2}\right), 92.2\left(\mathrm{C}_{\text {quat }}\right), 126.9$ $(\mathrm{CH}), 127.8(\mathrm{CH}), 128.9(\mathrm{CH})^{*}, 129.0(\mathrm{CH}), 130.2(\mathrm{CH}), 130.7$ $\left(\mathrm{C}_{\text {quat }}\right), 130.9(\mathrm{CH}), 131.7(\mathrm{CH}), 131.8\left(\mathrm{C}_{\text {quat }}\right), 132.9\left(\mathrm{C}_{\text {quat }}\right)$, $133.9(\mathrm{CH}), 153.1\left(\mathrm{C}_{\text {quat }}\right), 166.7\left(\mathrm{C}_{\text {quat }}\right), 193.4\left(\mathrm{C}_{\text {quat }}\right)$; *broadened signal; EIMS $\left.(\mathrm{m} / \mathrm{z}): 352\left(\left[\mathrm{M}-\mathrm{H}_{2} \mathrm{O}\right]\right)^{+}, 2\right), 266(11), 265$ $\left([\mathrm{M}-\mathrm{PhCO}]^{+}, 59\right), 248\left(\left[\mathrm{M}-\mathrm{PhCO}-\mathrm{H}_{2} \mathrm{O}\right]^{+}, 20\right), 105$ $\left(\mathrm{PhCO}^{+}, 100\right), 77\left(\mathrm{C}_{6} \mathrm{H}_{5}{ }^{+}, 34\right)$; IR (ATR), $\tilde{v}\left[\mathrm{~cm}^{-1}\right]$ : $3333(\mathrm{w})$, 1697 (m), 1626 (m), 1612 (m), 1566 (w), 1450 (m), 1427 (m), 1339 (m), 1315 (w), 1254 (w), 1202 (m), 1180 (m), 1113 (m), $1057(\mathrm{w}), 1028(\mathrm{w}), 922(\mathrm{w}), 895(\mathrm{w}), 866(\mathrm{~m}), 845(\mathrm{w}), 791$ (w), $762(\mathrm{~m}), 708(\mathrm{~s}), 689(\mathrm{~s}), 669(\mathrm{~m}), 627(\mathrm{w})$; anal. calcd for $\mathrm{C}_{23} \mathrm{H}_{18} \mathrm{~N}_{2} \mathrm{O}_{3}$ (370.4): C, 74.58; H, 4.90; N, 7.56; found: $\mathrm{C}$, 74.67; H, 5.07; N, 7.79. 


\section{Supporting Information}

For experimental details of the optimization studies on intermediate $\mathbf{3 a}$, on the cyclization step of $\mathbf{3 a}$ and $\mathbf{4 b}$ (compound $\mathbf{5 b}$ ), on the consecutive three-component synthesis of compound $\mathbf{5 b}$, experimental details of general procedure of the consecutive three-component synthesis and analytical data of 1,5-diacyl-5-hydroxypyrazolines $\mathbf{5}$, experimental details on the attempted dehydrative aromatization of compound $\mathbf{5 b}$, and NMR spectra of the compounds $\mathbf{5}$, and for summaries on the crystal structure analyses of 5a, 5r, and 6a see Supporting Information File 1.

\section{Supporting Information File 1}

Experimental details, copies of NMR spectra and crystallographic data.

[https://www.beilstein-journals.org/bjoc/content/ supplementary/1860-5397-15-136-S1.pdf]

\section{Acknowledgements}

The support of this work by the Fonds der Chemischen Industrie is gratefully acknowledged.

\section{Statement}

The reported results have been summarized in the inaugural dissertation "Diversitätsorientierte katalytische Ein-TopfSynthesen von ausgewählten Azolderivaten" by Dr. Christina Boersch, Heinrich Heine University Düsseldorf, 2014. Dr. Christina Görgen (née Boersch) is the first author of this article.

\section{ORCID ${ }^{\circledR} \mathrm{iDs}$}

Thomas J. J. Müller - https://orcid.org/0000-0001-9809-724X

\section{References}

1. Yet, L. Pyrazoles. In Comprehensive Heterocyclic Chemistry III; Katritzky, A. R.; Ramsden, C. A.; Scriven, E. F.; Taylor, R. J., Eds.; Elsevier: Oxford, 2008; Vol. 4, pp 3-141. doi:10.1016/b978-008044992-0.00401-6

2. Götzinger, A. C.; Müller, T. J. J. 12.1.5 Pyrazoles (Update 2017). In Science of Synthesis; Carreira, E. M.; Christmann, M.; Reissig, H.-U. Schaumann, E., Eds.; Georg Thieme Verlag: Stuttgart, New York, 2017; pp 1-228. doi:10.1055/sos-sd-112-00112

3. Stanovnik, B.; Svete, J. Product Class 1: Pyrazoles. In Category 2, Hetarenes and Related Ring Systems; Neier, R.; Bellus, D., Eds.; Science of Synthesis; Georg Thieme Verlag: Stuttgart, New York, 2002; pp 15-225. doi:10.1055/sos-sd-012-00002

4. Elguero, J.; Silva, A. M. S.; Tomé, A. C. Five-Membered Heterocycles: 1,2-Azoles. Part 1. Pyrazoles. In Modern Heterocyclic Chemistry; Alvarez-Builla, J.; Vaquero, J. J.; Barluenga, J., Eds.; Wiley-VCH: Weinheim, Germany, 2011; pp 635-725. doi:10.1002/9783527637737.ch8
5. Eicher, T.; Hauptmann, S. The Chemistry of Heterocycles, 2nd ed.; Wiley-VCH: Weinheim, Germany, 2003; pp 186-189. doi:10.1002/352760183x

6. Motoba, K.; Nishizawa, H.; Suzuki, T.; Hamaguchi, H.; Uchida, M.; Funayama, S. Pestic. Biochem. Physiol. 2000, 67, 73-84. doi:10.1006/pest.2000.2477

7. Beckmann, M.; Haack, K.-J. Chem. Unserer Zeit 2003, 37, 88-97. doi:10.1002/ciuz.200300268

8. Orth, R. E. J. Pharm. Sci. 1968, 57, 537-556. doi:10.1002/jps.2600570401

9. Chauhan, A.; Sharma, P. K.; Kaushik, N. Int. J. ChemTech Res. 2011, 3, 11-17.

10. Ismail, M. A. H.; Lehmann, J.; Abou El Ella, D. A.; Albohy, A.; Abouzid, K. A. M. Med. Chem. Res. 2009, 18, 725-744. doi:10.1007/s00044-009-9163-2

11. Stauffer, S. R.; Coletta, C. J.; Tedesco, R.; Nishiguchi, G.; Carlson, K.; Sun, J.; Katzenellenbogen, B. S.; Katzenellenbogen, J. A. J. Med. Chem. 2000, 43, 4934-4947. doi:10.1021/jm000170m

12. Singer, R. A.; Caron, S.; McDermott, R. E.; Arpin, P.; Do, N. M. Synthesis 2003, 1727-1731. doi:10.1055/s-2003-40881

13. Mukherjee, A.; Sarkar, A. Tetrahedron Lett. 2004, 45, 9525-9528. doi:10.1016/j.tetlet.2004.11.016

14. Dorlars, A.; Schellhammer, C.-W.; Schroeder, J. Angew. Chem., Int. Ed. Engl. 1975, 14, 665-679. doi:10.1002/anie.197506651

15. Catalan, J.; Fabero, F.; Claramunt, R. M.; Santa Maria, M. D.; de la Concepcion Foces-Foces, M.; Hernandez Cano, F.; Martinez-Ripoll, M.; Elguero, J.; Sastre, R. J. Am. Chem. Soc. 1992, 114, 5039-5048. doi:10.1021/ja00039a014

16. Yang, Z.; Zhang, K.; Gong, F.; Li, S.; Chen, J.; Ma, J. S.; Sobenina, L. N.; Mikhaleva, A. I.; Trofimov, B. A.; Yang, G. J. Photochem. Photobiol., A 2011, 217, 29-34. doi:10.1016/j.jphotochem.2010.09.012

17. Holla, B. S.; Akberali, P. M.; Shivananda, M. K. Farmaco 2000, 55, 256-263. doi:10.1016/s0014-827x(00)00030-6

18. Bansal, E.; Srivastava, V. K.; Kumar, A. Eur. J. Med. Chem. 2001, 36, 81-92. doi:10.1016/s0223-5234(00)01179-x

19. Ahn, J. H.; Kim, H.-M.; Jung, S. H.; Kang, S. K.; Kim, K. R.; Rhee, S. D.; Yang, S.-D.; Cheon, H. G.; Kim, S. S. Bioorg. Med. Chem. Lett. 2004, 14, 4461-4465. doi:10.1016/j.bmcl.2004.06.046

20. Rajendra Prasad, Y.; Lakshmana Rao, A.; Prasoona, L.; Murali, K.; Ravi Kumar, P. Bioorg. Med. Chem. Lett. 2005, 15, 5030-5034. doi:10.1016/j.bmcl.2005.08.040

21. Acharya, B. N.; Saraswat, D.; Tiwari, M.; Shrivastava, A. K.; Ghorpade, R.; Bapna, S.; Kaushik, M. P. Eur. J. Med. Chem. 2010, 45, 430-438. doi:10.1016/j.ejmech.2009.10.023

22. Ciupa, A.; De Bank, P. A.; Mahon, M. F.; Wood, P. J.; Caggiano, L. Med. Chem. Commun. 2013, 4, 956-961. doi:10.1039/c3md00077]

23. Nepali, K.; Singh, G.; Turan, A.; Agarwal, A.; Sapra, S.; Kumar, R.; Banerjee, U. C.; Verma, P. K.; Satti, N. K.; Gupta, M. K.; Suri, O. P.; Dhar, K. L. Bioorg. Med. Chem. 2011, 19, 1950-1958. doi:10.1016/j.bmc.2011.01.058

24. Machado, P.; Rosa, F. A.; Rossatto, M.; da S. Sant'Anna, G.; Sauzem, P. D.; Siqueira da Silva, R. M.; Rubin, M. A.; Ferreira, J.; Bonacorso, H. G.; Zanatta, N.; Martins, M. A. P. ARKIVOC 2007, No. xvi, 281-297. doi:10.3998/ark.5550190.0008.g28 
25. Sauzem, P. D.; Machado, P.; Rubin, M. A.; da S. Sant'Anna, G.; Faber, H. B.; de Souza, A. H.; Mello, C. F.; Beck, P.; Burrow, R. A.; Bonacorso, H. G.; Zanatta, N.; Martins, M. A. P. Eur. J. Med. Chem. 2008, 43, 1237-1247. doi:10.1016/j.ejmech.2007.07.018

26. Holla, B. S.; Udupa, K. V.; Sridhar, K. R. Bull. Chem. Soc. Jpn. 1989, 62, 3409-3411. doi:10.1246/bcsj.62.3409

27. Waldo, J. P.; Mehta, S.; Larock, R. C. J. Org. Chem. 2008, 73, 6666-6670. doi:10.1021/j0800789p

28. Joshi, K. C.; Bohra, R.; Joshi, B. S. Inorg. Chem. 1992, 31, 598-603. doi:10.1021/ic00030a014

29. Kumar Dey, D.; Lycka, A.; Mitra, S.; Rosair, G. M. J. Organomet. Chem. 2004, 689, 88-95. doi:10.1016/j.jorganchem.2003.09.035

30. de Sousa, G. F.; Garcia, E.; Gatto, C. C.; Resck, I. S.; Deflon, V. M.; Ardisson, J. D. J. Mol. Struct. 2010, 981, 46-53. doi:10.1016/j.molstruc.2010.07.023

31. Someya, C. I.; Inoue, S.; Irran, E.; Krackl, S.; Enthaler, S. Eur. J. Inorg. Chem. 2011, 2691-2697. doi:10.1002/ejic.201100248

32. Sevenard, D. V.; Khomutov, O. G.; Kodess, M. I.; Pashkevich, K. I.; Loop, I.; Lork, E.; Röschenthaler, G.-V. Can. J. Chem. 2001, 79, 183-194. doi:10.1139/v01-003

33. Zelenin, K. N.; Tugusheva, A. R.; Yakimovitch, S. I.; Alekseev, V. V.; Zerova, E. V. Chem. Heterocycl. Compd. 2002, 38, 668-676. doi:10.1023/a:1019909117505

34. Zelenin, K. N.; Alekseyev, V. V.; Tygysheva, A. R.; Yakimovitch, S. I. Tetrahedron 1995, 51, 11251-11256. doi:10.1016/0040-4020(95)00672-u

35. Rateb, L.; Azmy, B.; Nashed, M. A.; Iskander, M. F. Z. Naturforsch., B: Anorg. Chem., Org. Chem. 1978, 33, 1527-1534. doi:10.1515/znb-1978-1233

36. Bonacorso, H. G.; Wiethan, C. W.; Porte, L. M. F.; Moraes, M. C.; Navarini, J.; Belo, C. R.; Luz, F. M.; Zanatta, N.; Martins, M. A. P. ARKIVOC 2013, No. iv, 291-305. doi:10.3998/ark.5550190.p008.164

37. Martins, M. A. P.; Moreira, D. N.; Frizzo, C. P.; Longhi, K.; Zanatta, N.; Bonacorso, H. G. J. Braz. Chem. Soc. 2008, 19, 1361-1368. doi:10.1590/s0103-50532008000700019

38. Moreira, D. N.; Frizzo, C. P.; Longhi, K.; Zanatta, N.; Bonacorso, H. G.; Martins, M. A. P. Monatsh. Chem. 2008, 139, 1049-1054. doi:10.1007/s00706-008-0874-8

39. Martins, M. A. P.; Beck, P.; Machado, P.; Brondani, S.; Moura, S.; Zanatta, N.; Bonacorso, H. G.; Flores, A. F. C. J. Braz. Chem. Soc. 2006, 17, 408-411. doi:10.1590/s0103-50532006000200027

40. Buriol, L.; Frizzo, C. P.; Marzari, M. R. B.; Moreira, D. N.; Prola, L. D. T.; Zanatta, N.; Bonacorso, H. G.; Martins, M. A. P. J. Braz. Chem. Soc. 2010, 21, 1037-1044. doi:10.1590/s0103-50532010000600012

41. Lessing, T.; Müller, T. J. J. Appl. Sci. 2015, 5, 1803-1836. doi:10.3390/app5041803

42. D'Souza, D. M.; Müller, T. J. J. Chem. Soc. Rev. 2007, 36, 1095-1108. doi:10.1039/b608235c

43. Müller, T. J. J. Drug Discovery Today: Technol. 2018, 29, 19-26. doi:10.1016/j.ddtec.2018.06.003

44. Gers-Panther, C. F.; Müller, T. J. J. Multicomponent Synthesis of Heterocycles Initiated by Catalytic Generation of Ynones and Ynediones. In Advances in Heterocyclic Chemistry; Scriven, E. F. V.; Ramsden, C. A., Eds.; Academic Press, 2016; Vol. 120, pp 67-98. doi:10.1016/bs.aihch.2016.04.007

45. Müller, T. J. J. Top. Heterocycl. Chem. 2010, 25, 25-94. doi:10.1007/7081_2010_43
46. Willy, B.; Müller, T. J. J. Curr. Org. Chem. 2009, 13, 1777-1790. doi:10.2174/138527209789630479

47. Willy, B.; Müller, T. J. J. ARKIVOC 2008, No. i, 195-208. doi:10.3998/ark.5550190.0009.107

48. Merkul, E.; Dohe, J.; Gers, C.; Rominger, F.; Müller, T. J. J. Angew. Chem., Int. Ed. 2011, 50, 2966-2969. doi:10.1002/anie.201007194

49. Boersch, C.; Merkul, E.; Müller, T. J. J. Angew. Chem., Int. Ed. 2011, 50, 10448-10452. doi:10.1002/anie.201103296

50. Merkt, F. K.; Höwedes, S. P.; Gers-Panther, C. F.; Gruber, I.; Janiak, C.; Müller, T. J. J. Chem. - Eur. J. 2018, 24, 8114-8125. doi:10.1002/chem.201800079

51. Gers-Panther, C. F.; Fischer, H.; Nordmann, J.; Seiler, T.; Behnke, T.; Würth, C.; Frank, W.; Resch-Genger, U.; Müller, T. J. J. J. Org. Chem. 2017, 82, 567-578. doi:10.1021/acs.joc.6b02581

52. Gers, C. F.; Nordmann, J.; Kumru, C.; Frank, W.; Müller, T. J. J. J. Org. Chem. 2014, 79, 3296-3310. doi:10.1021/j04025978

53. CCDC 1902138 (5a), CCDC 1906570 (5r), and CCDC 1906571 (6a) contain the supplementary crystallographic data (excluding structure factors) for this paper. These data are provided free of charge by The Cambridge Crystallographic Data Centre.

\section{License and Terms}

This is an Open Access article under the terms of the Creative Commons Attribution License (http://creativecommons.org/licenses/by/4.0). Please note that the reuse, redistribution and reproduction in particular requires that the authors and source are credited.

The license is subject to the Beilstein Journal of Organic Chemistry terms and conditions:

(https://www.beilstein-journals.org/bjoc)

The definitive version of this article is the electronic one which can be found at: doi:10.3762/bjoc. 15.136 